\title{
Progress in the study of cholupa (Passiflora maliformis L.) phenology in producing areas of Colombia
}

\author{
Avances en el estudio de la fenología de la cholupa \\ (Passiflora maliformis L.) en áreas productivas de Colombia
}
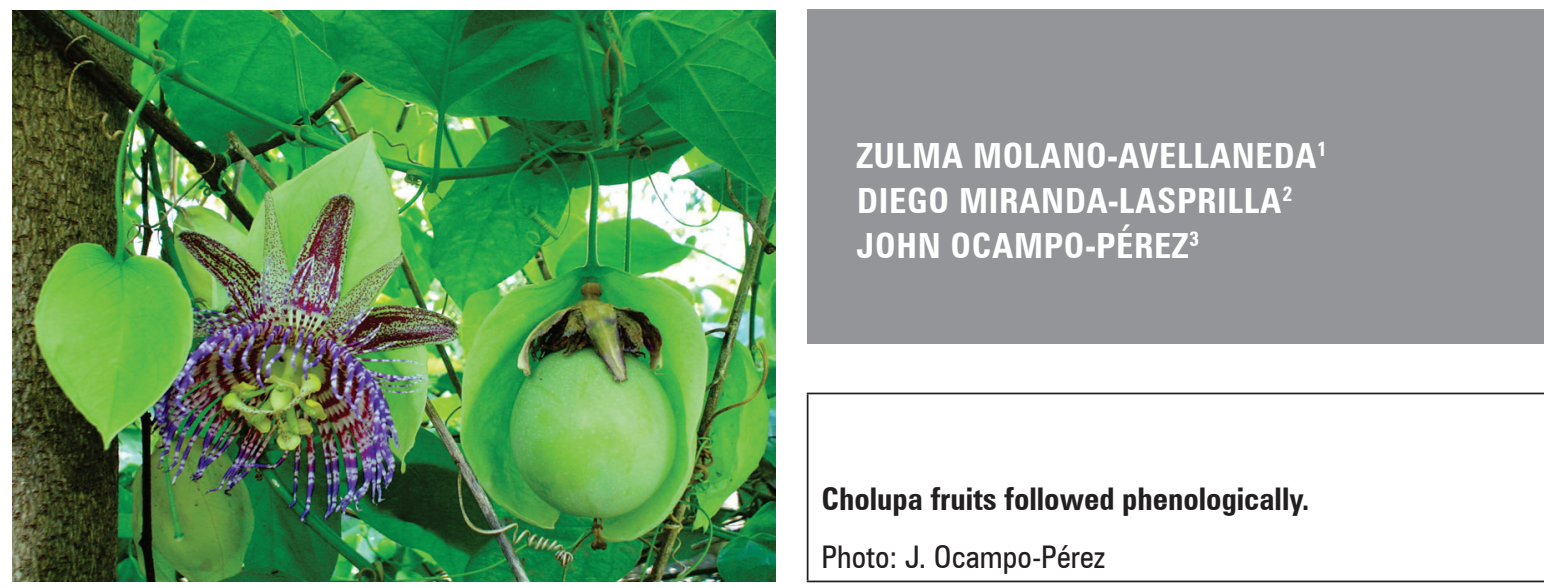

\begin{abstract}
The cholupa or stone granadilla (Passiflora maliformis L.) is one of the eight cultivated species in the genus Passiflora L. However, the phenological development of this species has not been investigated. This study aimed to assess some phenological aspects of cholupa growth in the vegetative and reproductive phases in the town of Rivera (Colombia). The plant phenology during the vegetative and reproductive phases of growth was evaluated with weekly measurements of the length and number of stem nodes, primary and secondary branches, and longitudinal and transverse fruit diameters in commercial crops. The curves described the dynamics of growth in the main stem and primary and secondary branches and their respective equations using the curve fitting technique, which was fit to sigmoidal-logistic models with high statistical reliability. The time from anthesis to fruit maturity was between 50 and 60 days; the final longitudinal and transverse diameters averaged 54 and $53 \mathrm{~mm}$, respectively. The phenological BBCH scale was established for the major phenological stages (E1: leaf development of the main stem, E3: stem elongation, E5 and E6: appearance and development of floral organs and flowering, and E7: fruit development). These aspects of cholupa development were similar to reports on other Passiflora species, providing very useful results for defining agronomic practices in cultivation and breeding programs.
\end{abstract}

Additional key words: growth curves; development stages; $\mathrm{BBCH}$; stone granadilla; Passifloraceae.

Corporación de Desarrollo Tecnológico CEPASS, Neiva (Colombia). ORCID Molano, Z.: 0000-0002-3558-0610

2 Universidad Nacional de Colombia, Facultad de Ciencias Agrarias, Bogota (Colombia). ORCID Miranda-Lasprilla, D.: 0000-0001-9861-6935

${ }_{3}$ Universidad Nacional de Colombia, Palmira (Colombia). ORCID Ocampo-Pérez, J.: 0000-0002-2720-7824 


\section{RESUMEN}

La cholupa o stone granadilla (Passiflora maliformis L.) es una de las ocho especies cultivadas del género Passiflora L. Sin embargo, el conocimiento sobre el desarrollo fenológico de esta especie no se ha investigado. Este estudio tuvo como objetivo evaluar algunos aspectos de la fenología del crecimiento de cholupa en las fases vegetativa y reproductiva en la ciudad de Rivera (Colombia). Para esto, se evaluó la fenología de las plantas durante las fases vegetativas y reproductivas del crecimiento mediante mediciones semanales de la longitud y el número de nudos del tallo, ramas primarias y secundarias, y el diámetro longitudinal y transversal del fruto en cultivos comerciales. Se obtuvieron las curvas que describen la dinámica de crecimiento del tallo principal y las ramas primarias y secundarias y sus respectivas ecuaciones mediante la técnica de ajuste de curvas, que se ajustó a modelos sigmoidales-logísticos con alta confiabilidad estadística. El tiempo desde la antesis hasta la madurez del fruto fue entre 50 y 60 días; los diámetros longitudinales y transversales finales promediaron 54 y $53 \mathrm{~mm}$, respectivamente. La escala fenológica $\mathrm{BBCH}$ se estableció para las principales etapas fenológicas (E1: desarrollo de la hoja del tallo principal, E3: alargamiento del tallo, E5 y E6: apariencia y desarrollo de los órganos florales y floración, y E7: desarrollo del fruto). Estos aspectos del desarrollo de la cholupa fueron similares a los reportados para otras especies de Passiflora y son resultados muy útiles para definir las prácticas agronómicas en los programas de cultivo y reproducción.

Palabras clave adicionales: curva de crecimiento; estados de desarrollo; $\mathrm{BBCH}$; stone granadilla; Passifloraceae.

Received for publication: 23-02-2020 Accepted for publication: 30-03-2020
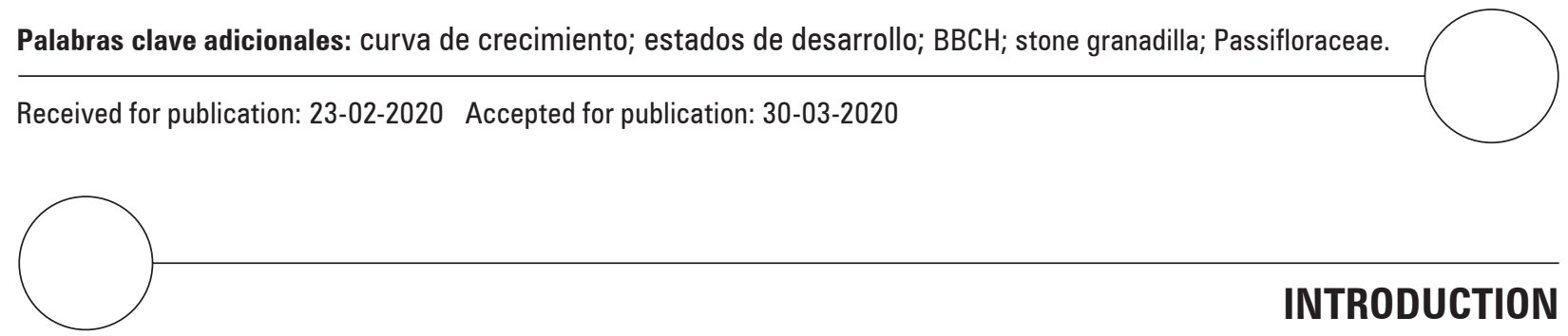

INTRODUCTION

The cholupa or stone granadilla (Passiflora maliformis L.) is one of the eight cultivated species in the genus Passiflora, such as yellow passion fruits (Ocampo et al., 2015a), sweet granadillas (Ocampo et al., 2015b), and others with agronomic potential (Hurtado-Salazar et al., 2020). This species is native to northern Ecuador, Colombia, Venezuela and the Antilles and was introduced to Europe as an ornamental plant in greenhouses. The flower is hermaphrodite with a high degree of self-incompatibility (95\%), and is cross-pollinated (allogamy) mainly by insects of the genus Xylocopa spp. (Ocampo et al., 2015a). The fruits are characterized by a high content of total phenols (277.00 mg gallic acid equivalent/L fresh weight-FW) and the total antioxidant activity $(1,685.00 \mu \mathrm{mol}$ Trolox/L FW) (Fischer et al., 2018). The cultivation of the cholupa has become a line of economic and social importance in the Department of Huila, Colombia, because of its high profitability and the generation of rural jobs, which can reach 648 wages per hectare for a three-year cycle. Cholupa is grown commercially in 14 municipalities with about 200 ha, Rivera being the principal one. In Huila, around 1,200 t of fruit were produced in 2018 (Agronet, 2019), of which $10 \%$ were pre or post-harvest losses, and $90 \%$ were destined for consumption in the regional market as fresh fruit, mainly in the preparation of juices. The production behavior throughout the year is continuous, with two marked harvest times: the first is October to January, the last two months having the highest production, and the second is from the first week of April to the end of May.

The effect of physical, chemical and biotic environments on the physiological mechanisms of a plant is known as plant ecophysiology (Larcher, 2003). The cholupa is cultivated in Colombia between 600-1,000 $\mathrm{m}$ a.s.1. (Ocampo et al., 2015a), with temperatures between 26 and $32^{\circ} \mathrm{C}$, rainfall between 1,200 and 1,450 $\mathrm{mm}$, relative humidity between 60 and $70 \%$, and 8-11 $\mathrm{h}$ light/d (Fischer et al., 2018). These ecological conditions greatly affect the duration of the phenological stages of the plant (Fischer et al., 2009).

The study of biological events and their causes as a function of biotic and abiotic factors, as well as their relationship between the phases characterized by these events, within one or more species, is known as phenology (Silva et al., 2007). Phenological characterizations through the stages of the phenophases (vegetative and reproductive) provide greater detail in the description of plant cycle, helping in the prediction of seed collection for seed production and in the conservation and breeding 
programs of the species (Rego et al., 2006). Furthermore, the phenological identification of growth stages of mono- and dicotyledonous plant species uses the extended $\mathrm{BBCH}$ scale, an acronym of Biologische Bundesanstalt, Bundessortenamt und Chemical Industry (Meier, 2001). The scale has 10 main stages or plant development stages that are clearly identifiable and visible, starting with budbreak (stage 0) and ending with the latency period (stage 9); intermediate values include leaf development, buds, flowers, fruit development and subsequent ripening; secondary stages are also listed from 0 to 9 and are related to ordinal or percentage values of development (Mayor, 2011). Another useful tool to identify the physiological behavior of fruit species uses growth curves and development events, which are genetically determined, hormonally regulated and can be modified by environmental conditions (Garriz et al., 2005). They strengthen knowledge on a system (López et al., 2005), evaluate possible management strategies, and provide an approach for the potential yield (Cañizares et al., 2003). Among the non-linear models used to characterize growth and/or development as a function of time, the logistic, the exponential, and the monomolecular models stand out (García, 2008; Moreno-Medina et al., 2016; Almanza-Merchán et al., 2017).

Although there is an empirical knowledge from cholupa producers on the duration and the time (in the year) where the most interesting phenological events take place (Ocampo et al., 2015a), these events have not been described according to the $\mathrm{BBCH}$ scale, and there is no information on growth and development under this climatic condition. Therefore, the present study was proposed to identify the main phenological stages and approximate times of duration in order to generate a guide that estimates some growth and development parameters that help achieve integrated crop management.

\section{MATERIALS AND METHODS}

The study was carried out in the municipality of Rivera (02 44'29.4' N, 075'77'19.5" W), province of Huila (Colombia), located at $595 \mathrm{~m}$ a.s.l., during the period of December, 2014 to December, 2015. The fruit growth curve was used on a commercial crop in the municipality of Campoalegre $\left(2^{\circ} 43^{\prime} 26.9^{\prime \prime} \mathrm{N}\right.$, $\left.75^{\circ} 15^{\prime} 50.7^{\prime \prime} \mathrm{W}\right)$, located at $788 \mathrm{~m}$ a.s.1., with an average temperature of $27^{\circ} \mathrm{C}$ and a relative humidity of $65 \%$. The plants, $15 \mathrm{~d}$ old in a $4 \times 4 \mathrm{~m}$ arrangement, were evaluated with a trellis system that consisted of a $2 \mathrm{~m}$ high mesh, on which the different types of crop branches were conducted and fixed. The climate of the region is classified as As according to Köppen, dry tropical area with a dry summer. For the characterization of meteorological conditions during the experiment, the climatological data, relative humidity $(\mathrm{RH}, \%)$ and temperature $\left({ }^{\circ} \mathrm{C}\right)$ were obtained from datalogger weather sensors (Onset HOBO UX100003 humidity and temperature data logger, Micro$\mathrm{DAQ}$, Contoocook, $\mathrm{NH}$ ) every $6 \mathrm{~h}$, with an accuracy of $3.5 \%$. The precipitation variable was taken from climate databases (Wordclim).

Starting at 18 days after planting (DAP), the following variables were recorded weekly for 150 DAP in the selected plants: Length $(\mathrm{cm})$ and number of nodes of the main stem and primary and secondary branches. Subsequently, for the fruit growth curve, ten flowers were marked in anthesis and weekly records were taken of the longitudinal and the transverse diameters of ten fruits per plant until ripening. the One plant was the sampling unit for the growth variables. The variables of each sample were used to model growth with the logistic function (1)

$$
Y=\frac{\alpha}{1+\operatorname{Exp}(b-c \times X)}
$$

Where, $\alpha$, the upper asymptote, is the maximum magnitude of the variable, $c$ is the parameter that determines the slope of the curve, $b$ is the moment when the maximum growth rate is achieved and $X$ is the time (Seber and Wild, 1989). Based on these coefficients, obtained with STATISTIX 9, 2008, the growth curves for the plants established in the field were obtained. The BBCH-scale was used to identify the phenological development stages of the plants.

\section{RESULTS AND DISCUSSION}

\section{Behavior of climatic variables}

For the average temperature (Fig. 1A), an irregular behavior was observed with values between 21 and $30^{\circ} \mathrm{C}$ and marked peaks for the months of February and March, 2015 (39.4 and $37.3^{\circ} \mathrm{C}$, respectively). An oscillating trend was observed for the relative humidity throughout the evaluation; the lowest values were in the month of February, 2015 (Fig. 1B). During this period, a high rate of vegetative growth of the stem and primary branches was detected. 

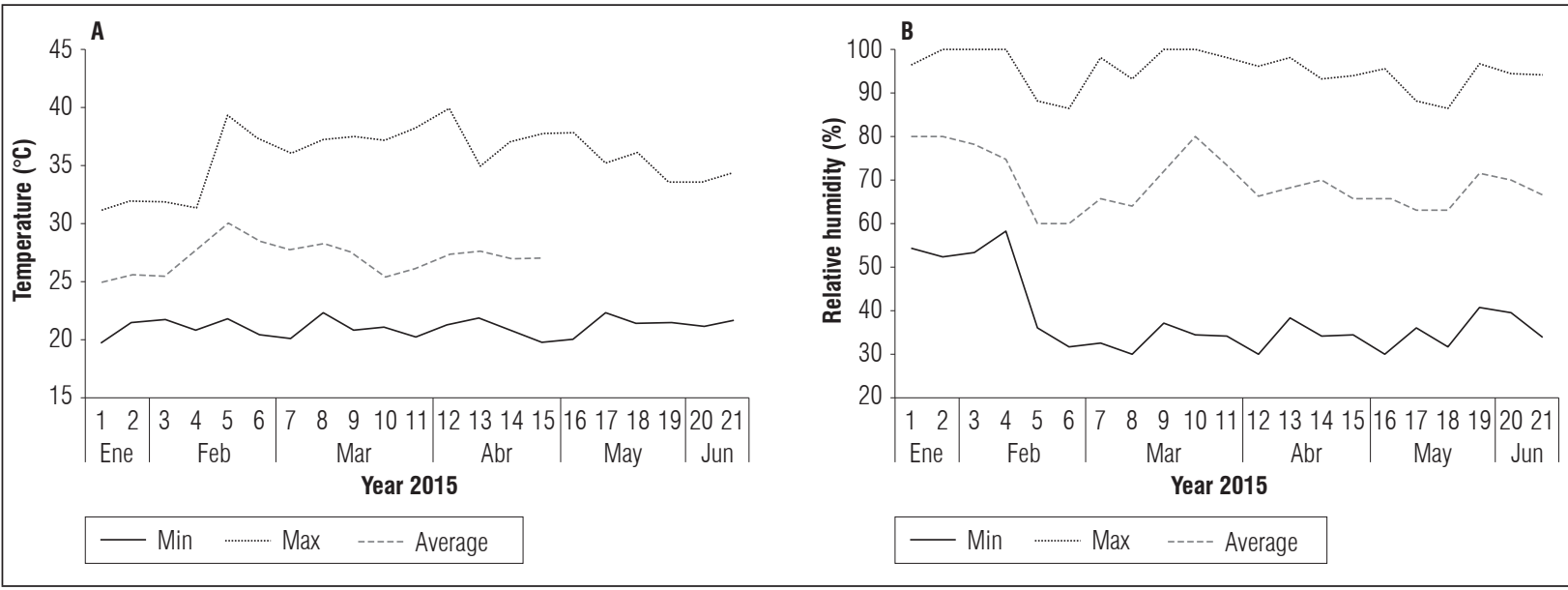

Figure 1. Behavior of (A) temperature and (B) relative humidity in the municipality of Rivera, Huila for 2015.

Differences were observed between the daytime and nighttime temperatures, with fluctuations of $19.7^{\circ} \mathrm{C}$; likewise, at night, the $\mathrm{RH}$ reached $99.8 \%$, which was a positive condition for the occurrence of diseases, and, during the day, it dropped to $32.2 \%$, with a difference of $67.7 \%$ between the $2 \mathrm{~d}$. It should be noted that this low RH caused dehydration of the pollen and stigmatic fluid, reducing the fertilization process and facilitating flower abortion (Ocampo, 2013; Fischer et al., 2009).

\section{Vegetative phase}

During the vegetative phase, the development stages 1 (leaf development) and 3 (main stem elongation) were identified according to the $\mathrm{BBCH}$ scale (Meier, 2001). The times are presented in days after planting (DAP), averaging the date on which $50 \%$ of the plants reached each stage of development.

In the principal growth stage 1 (Tab. 1), it was possible to identify the secondary stages corresponding to the development of the third leaf (code 13) on day 6 DAP, along with the appearance of the fifth leaf (code $15)$ at $10 \mathrm{DAP}$, until obtaining nine true leaves $(\mathrm{BBCH}$ code 19) on 17 DAP. Afterwards, the development of new leaves continued, and it is possible to observe the appearance of the first tendril accompanying leaves, which had the characteristic climber habit of these species, one of the parameters that producers take into account when transplanting to the definitive place, along with the height of the plant.

The cholupa is characterized as a liana whose growth is continuous, with lateral flowering and basitonic branching (Tovar, 2009). During its development, lateral shoots begin to appear in the basal portion, below and above the knot with the first tendril.

\section{Growth and development of the principal stem}

This plant is a climbing semi-perennial vine, with a cylindrical stem, glabrous or finely pubescent, green in color, striated, herbaceous and woody towards the base, with up to $12 \mathrm{~cm}$ in diameter (Ocampo et al., 2015a). At 23 DAP, the main stem reached an average of $37.03 \mathrm{~cm}$. Starting at 30 DAP, the plants increased the growth rate, which, at $88 \mathrm{DAP}$, reached a maximum length of $455 \mathrm{~cm}$, with a total of 68 nodes, presenting an emission rate of 2.8 nodes per week (Fig. 2) and an $R^{2}$ of 0.91 (Tab. 2). Schwartz (2013) stated that the phenological stages are good indicators of plant development rates, and, according to Angulo (2003), this behavior can be calculated with the period that lapses from node appearance to the appearance of the next node. At that time, pruning was carried out with cutting. The cut was made at the top of the node in order to activate lateral buds to stimulate the emission of the primary branches.

\section{Growth and development of primary branches}

The branches can reach up to $30 \mathrm{~m}$ in length, with knots and internodes that form a lower bud, two linear, stipulated provisions (orange), a leaf and a tendril that provide plant support for the plant (Ocampo et al., 2015a). According to the typical behavior of passion flower crops, the growth of lateral shoots is successive, meaning that vegetative primary branches 


\section{Table 1. BBCH scale established for the growth and development of cholupa (P. maliformis) in Colombia.}

\begin{tabular}{|c|l|c|}
\hline \multicolumn{3}{|c|}{ Phenological growth stages } \\
\hline BBCH & \multicolumn{1}{|c|}{ Description } & DAP \\
\hline 10 & Total developed cotyledons & n.d \\
\hline 11 & Development of the first leaf & n.d \\
\hline 12 & Development of the second leaf & n.d \\
\hline 13 & Development of the third leaf & 6 \\
\hline 14 & Development of the fourth leaf & 8 \\
\hline 15 & Development of the fifth leaf & 10 \\
\hline 16 & Development of the sixth leaf & 12 \\
\hline 17 & Development of the seventh leaf & 14 \\
\hline 18 & Development of the eighth leaf & 15 \\
\hline 19 & Development of the ninth leaf & 17 \\
\hline & Principal growth stage 3: main stem development \\
\hline 31 & $10 \%$ of maximum length of the main stem & 25 \\
\hline 32 & $20 \%$ of maximum length of the main stem & 34 \\
\hline 33 & $30 \%$ of maximum length of the main stem & 42 \\
\hline 34 & $40 \%$ of maximum length of the main stem & 47 \\
\hline 35 & $50 \%$ of maximum length of the main stem & 52 \\
\hline 36 & $60 \%$ of maximum length of the main stem & 57 \\
\hline 37 & $70 \%$ of maximum length of the main stem & 66 \\
\hline 38 & $80 \%$ of maximum length of the main stem & 71 \\
\hline 39 & $\begin{array}{l}\text { The main stem of the plant reached } 90 \%-100 \% \\
\text { of its maximum length. }\end{array}$ & 80 \\
\hline & & \\
\hline
\end{tabular}

Principal growth stage 5 and 6 : inflorescence emergence and flowering

\begin{tabular}{|c|l|c|}
\hline 51 & Visible floral bud & 90 \\
\hline 55 & $\begin{array}{l}\text { Floral cartridge with 50\% of the characteristic size } \\
\text { of the species }\end{array}$ & 95 \\
\hline 58 & Maximum size of the floral cartridge & 99 \\
\hline 61 & Beginning of flowering: 10\% of flowers are open & 100 \\
\hline 65 & Full bloom. 50\% of flowers in anthesis & 108 \\
\hline 69 & End of flowering: fruit set & 112 \\
\hline & \multicolumn{2}{|l|}{ Principal growth stage 7: development of fruit } \\
\hline 70 & Visible fruit & 114 \\
\hline 71 & The fruit reaches 10\% of the final size & 117 \\
\hline 72 & The fruit reaches 20\% of the final size & 121 \\
\hline 73 & The fruit reaches 30\% of the final size & 126 \\
\hline 74 & The fruit reaches 40\% of the final size & 132 \\
\hline 75 & The fruit reaches 50\% of the final size & 140 \\
\hline 76 & The fruit reaches 60\% of the final size & 150 \\
\hline 77 & The fruit reaches 75\% of the final size & 161 \\
\hline 78 & The fruit reaches 90\% of the final size & 173 \\
\hline 79 & Fruit has reached typical form and size & 180 \\
\hline
\end{tabular}

$\mathrm{DAP}=$ days after planting.
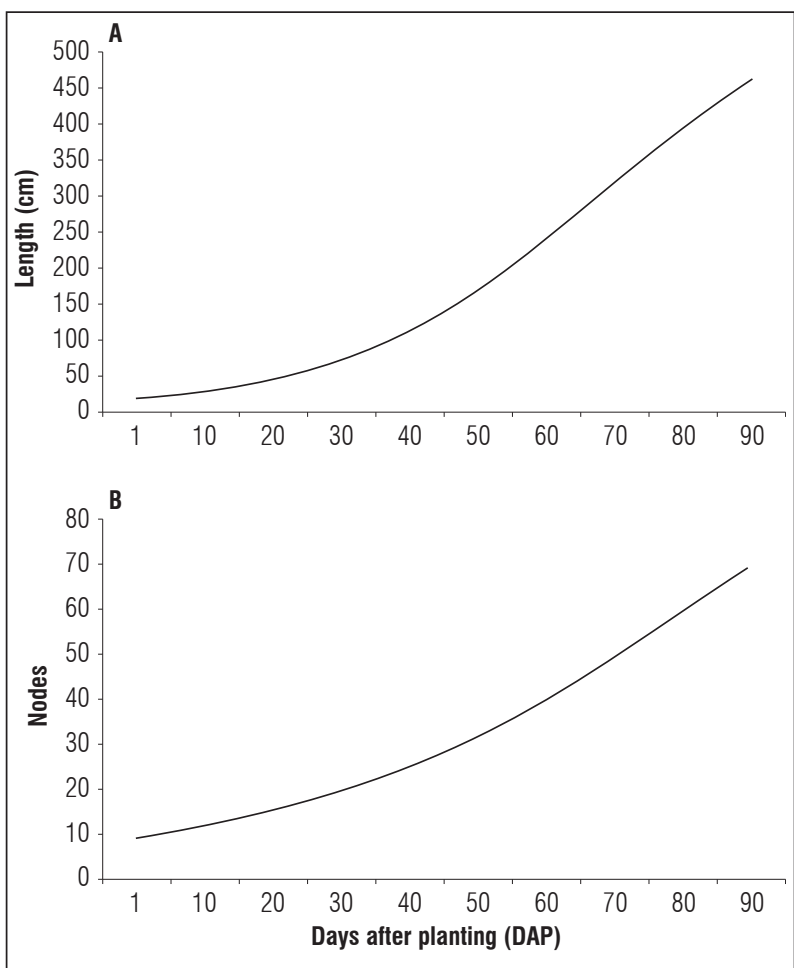

Figure 2. Length $(A)$ and average number of nodes $(B)$ of the main stem of cholupa (P. maliformis) plants.

are generated from the main stem; afterwards, secondary branches originate from nodes of the primary branches, which, in the first production cycle, make up the group called "loaders or producers", along with some tertiary branches, which must be thicker to support the weight of the reproductive structures that become fruit The curves for the length of the primary branching were sigmoid curves, characterized by a very rapid growth phase because of the budding response of the vegetative buds after emergence (Fig. 3).

The maximum length of the primary branches (214 $\mathrm{cm}$ ) was achieved near day 57 after pruning, along with the greatest number of nodes (35) in the evaluated period, with an emission rate of 0.86 nodes per day. After the emergence of the primary branches, the re-sprouting of secondary and tertiary branches begins because, physiologically, there is always a branch bud and the anterior buds break their dormancy.

\section{Growth and development of secondary branches}

The length and number of nodes of the secondary branches adjusted to the logistic model of three 
Table 2. Equation of growth parameters in cholupa (P. maliformis) plants.

\begin{tabular}{|c|c|c|}
\hline Parameter & Equation & Pseudo $R^{2}$ \\
\hline Length of the main stem & $Y=\frac{615.66}{1+\operatorname{Exp}(3.5987-0.0525 \times D A P)}$ & 0.9165 \\
\hline Number of nodes of the main stem & $Y=\frac{153.38}{1+\operatorname{Exp}(2.8092-0.0327 \times D A P)}$ & 0.9181 \\
\hline Length of the primary branches & $Y=\frac{225.35}{1+\operatorname{Exp}(5.0968-0.1621 \times D A P)}$ & 0.8921 \\
\hline Number of nodes of the primary branches & $Y=\frac{42.45815}{1+\operatorname{Exp}(2.7818-0.0899 \times D A P)}$ & 0.884 \\
\hline Length of the secondary branches & $Y=\frac{143.8392}{1+\operatorname{Exp}(2.7323-0.1934 \times D A P)}$ & 0.8137 \\
\hline Number of nodes of the secondary branches & $Y=\frac{29.92532}{1+\operatorname{Exp}(1.79061-0.1115 \times D A P)}$ & 0.73 \\
\hline Longitudinal diameter of the fruit & $Y=\frac{54.069}{1+\operatorname{Exp}(2.2440-0.4571 \times D A P)}$ & 0.8752 \\
\hline Transverse diameter of the fruit & $Y=\frac{54.361}{1+\operatorname{Exp}(2.8669-0.4888 \times D A P)}$ & 0.870 \\
\hline
\end{tabular}
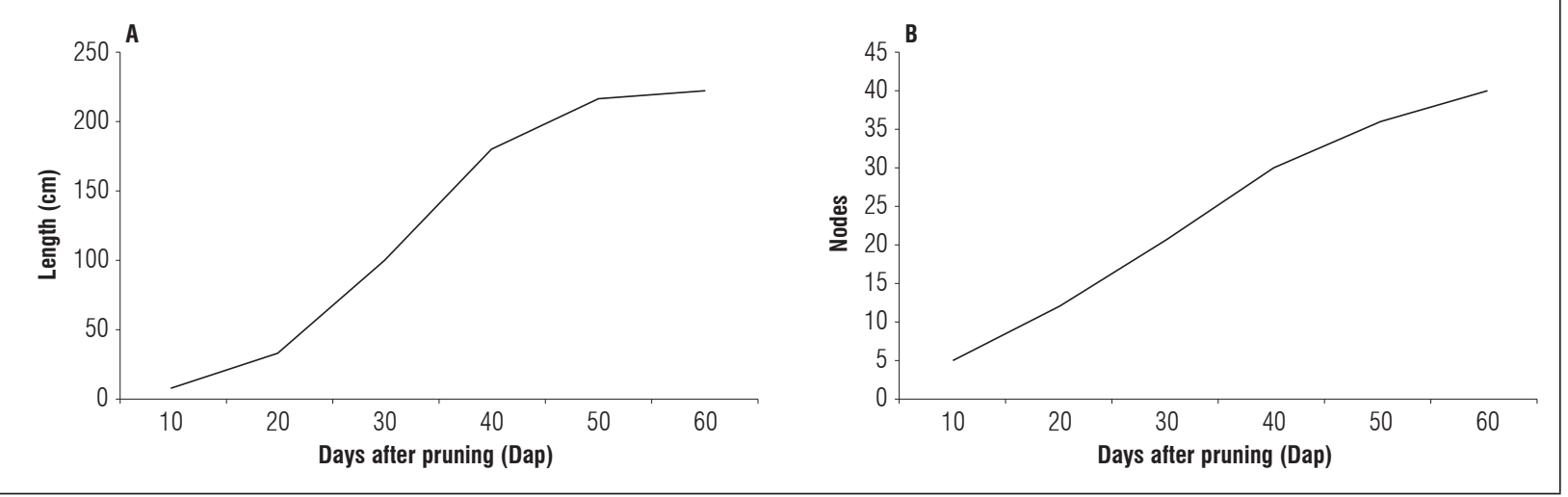

Figure 3. Length (A) and average number of nodes (B) of the primary branches of cholupa (P. maliformis) plants.

parameters over time; the highest average value was $138.4 \mathrm{~cm}$, reaching maximum length approximately on 30 DAP (Fig. 4). The maximum number of nodes was achieved at 25-30 DAP (Fig. 4B), and the final number of nodes was 30 . Thus, the rate of emission of nodes in the secondary branches in the initial phase (6-14 DAP) was 12 nodes per day, decreasing progressively, until reaching 0.9 . This condition could be due to the presence of thrips (Neohydatothrips sp.) that caused damage to the terminal shoots and retarded branch growth but not the emission of nodes, resulting in branches with shorter internodes than healthy branches (longer internodes) (Santos et al., 2012). 

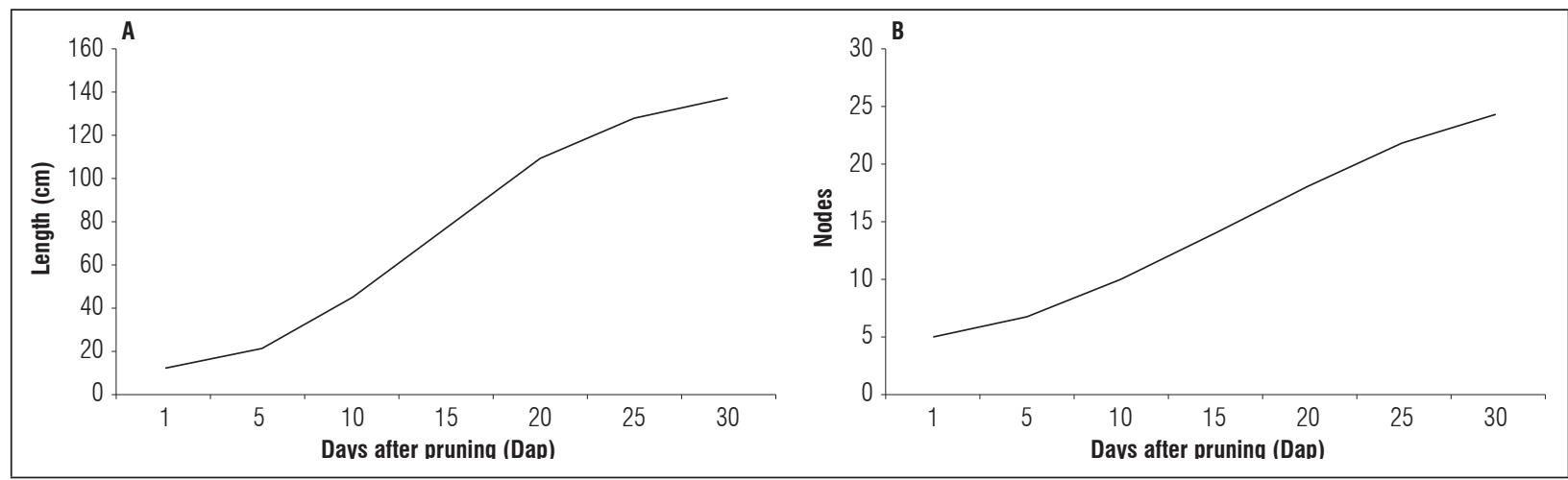

Figure 4. Length (A) and average number of nodes (B) of the secondary branches of cholupa (Passiflora maliformis $L$.) plants.

The description of stage 39 with the elongation of the main stem (Tab. 1) included the maximum length of the main stem, $4.0 \mathrm{~m}$, with a tutored system with an average height of $2 \mathrm{~m}$. The grower allowed growth of the stem $2 \mathrm{~m}$ beyond the wiring before emergence and stimulated primary branch growth. Ten percent of the main stem growth of the cholupa was reached at $25 \mathrm{DAP}$ on average, $50 \%$ was reached at $52 \mathrm{DAP}$, and $100 \%$ was obtained at approximately 80 DAP. The leaves are inserted on the stem using a petiole that is 2.3 to $8.5 \mathrm{~cm}$ in length with two subsesile glands (eventually two pairs), located in the lower half. The peduncle can have 3 to $9.5 \mathrm{~cm}$ in length and three bracts (cap) at its apex that are green and resemble leaves that are 5 to $8 \mathrm{~cm}$ long and 2.5 to $5 \mathrm{~cm}$ wide, which protect the flower and fruit in the stages of development (Ocampo et al., 2015a) (Fig. 5).

\section{Reproductive phase}

In the Passiflora species family, as in the cholupa, a stage of completely vegetative growth (juvenile phase of crop development) occurs with subsequent annual cycles of growth, where vegetative and reproductive stages occur simultaneously or slightly overlapping (Melgarejo et al., 2015). This fact results from the indeterminate growth habit of the crop, the origin and the adaptation to environments where it currently grows. The apex of growth of all branches is apt to form a floral primordium at the level of each node. The reproductive phase begins with the appearance of flower buds and ends with fruit ripening, in which the fruit has developed characteristics of appearance and texture, which is related to physicochemical changes in the pulp, such as flavor and aroma. Stages 5 and 6 include the appearance and development of the floral organ and flowering (Fig. 6 and Tab. 1). This process was evaluated on the secondary branches of the crop because it was the first cycle of production. The stages were identified from the emergence of the floral bud (stage 51), which is known as a floral cartridge until it reaches its maximum size (stage 58), where all parts of the flower are fully developed
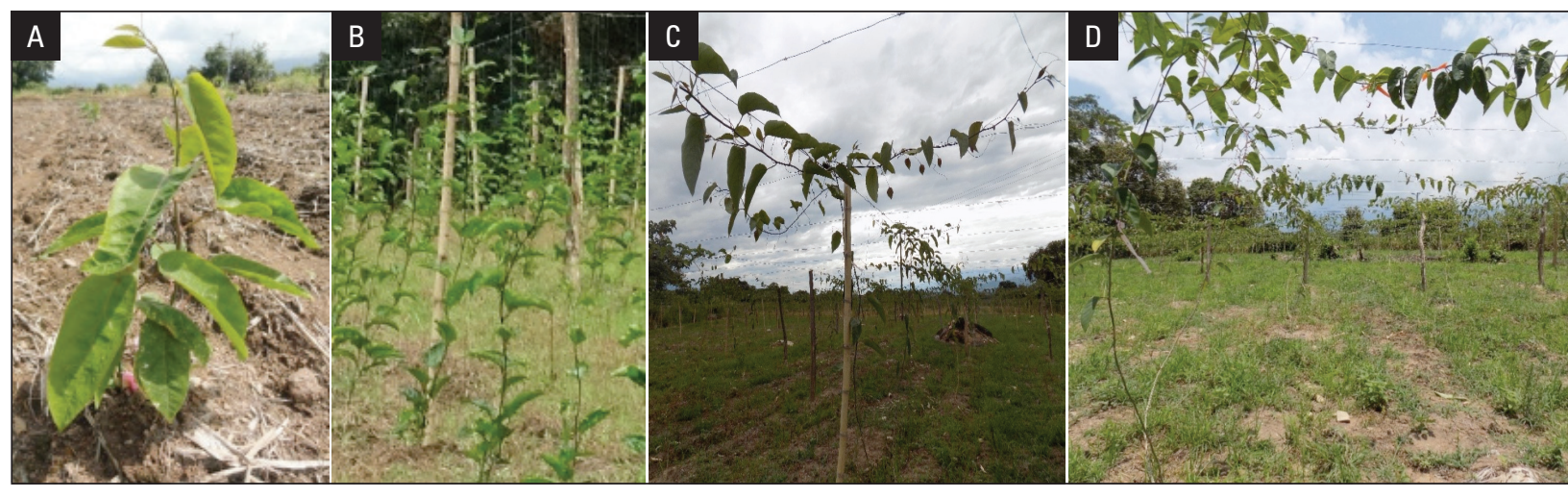

Figure 5. Principal growth stage 3: main stem development in cholupa (P. maliformis) plants. 5a) Stage 19, development of the ninth leaf. 5b) Stage 34, $40 \%$ of maximum length of the main stem. 5c) Stage 33, 70\% of maximum length of the main stem. 5d) Stage 39, the main stem of the plant has reached $90 \%-100 \%$ of its maximum length. 
and the process of floral opening begins. The flower is generally alone, or rarely in pairs, pendular, pentamera, hermaphrodite, showy and with a pleasant aroma, with a length of 4.5 to $6.5 \mathrm{~cm}$ and a width of 4 to $5 \mathrm{~cm}$, along with five petals and five sepals, lanceolate, reflexed, white and an interior mottled redpurple color (Ocampo et al., 2015a) (Fig. 6).

The full flowering (stage 65) and end of flowering or fruit set (stage 69) were also established. It should be noted that, in cholupa crops, the process of floral opening, pollination and flower closure takes place in
$12 \mathrm{~h}$, and the fruit set is estimated at approximately 2 days after anthesis (DAA).

The beginning of flowering is not uniform because plants originate from seeds, and the species is allogamous (Tovar, 2009). Flowering begins with the appearance of flowers on the lateral and basal branches. The flower, one per leaf axilla, is ephemeral, and anthesis takes only $12 \mathrm{~h}$ (Tovar, 2009). The first flowers in anthesis were observed at 108-110 DAP, and, at $180 \mathrm{DAP}$, the first ripe fruits were received. However, a high abortion of flowers was observed before
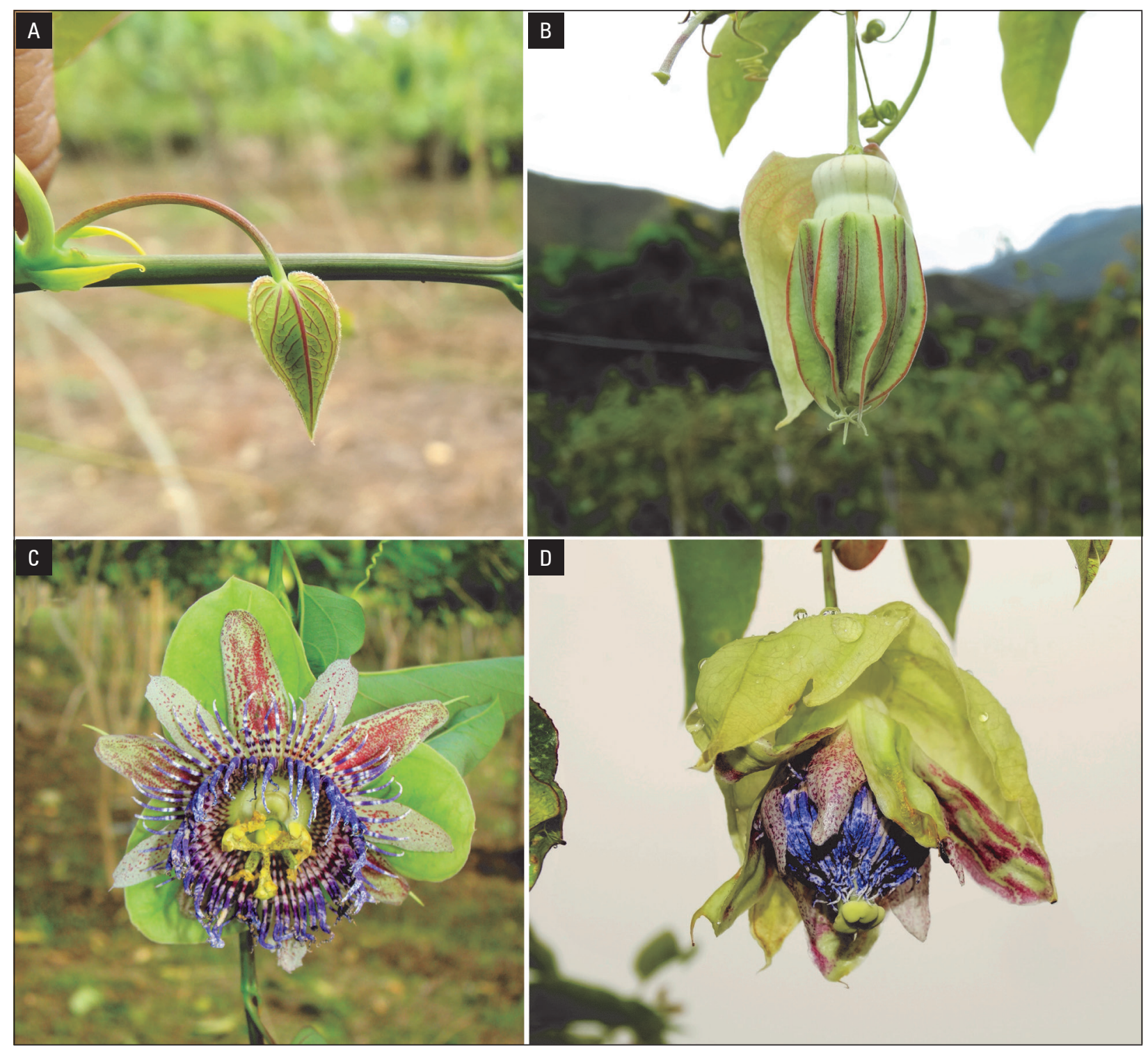

Figure 6. Principal growth stages 5 and 6: inflorescence emergence and flowering in cholupa ( $P$. maliformis) plants. 5a) Stage 5. Stage 51: Visible floral bud. 5b) Stage 58, maximum size of the floral cartridge. d) Stage 6. Stage 61, Beginning of flowering: $10 \%$ of flowers are open and stage 65 , full bloom. $50 \%$ of flowers in anthesis. 
anthesis, which was manifested by the presence of vain structures between the apex and the flowers. After this event, a new fall of flowers can be explained by natural abortion, excess humidity and/or lack of pollination, which turns into a decrease in production since it has been indicated that $67 \%$ of production and fruit quality depend on pollinators that decrease activity at that time (Tovar, 2009).

The $\mathrm{BBCH}$ codes with the respective description for stage 7: fruit formation (Fig. 7 and Tab. 1) was determined at $117 \mathrm{DAP}$, which is equivalent to a fruit between $7-10 \%$ of the final size, following the $\mathrm{BBCH}$ stages for fruit growth (stages $71-78$ ), where $50 \%$ of the fruit size is reached at $140 \mathrm{DAP}, 75 \%$ of the size is achieved by $161 \mathrm{DAP}, 90 \%$ is seen by $180 \mathrm{DAP}$, and, finally, the maximum size on average is reached at
185 DAP. The fruits, upon maturation, did not have a color change, so abscission above the bracts that support it is used as an indicator of maturity.

\section{Growth and development of fruits}

The fruit is a berry in shape, spherical or ovoid, with an extremely hard shell (pericarp) (eventually soft) that is smooth and waxy, about 3.0 to $4.5 \mathrm{~mm}$ thick, with a white mesocarp (Ocampo et al., 2015a). Among the factors that determine development and final fruit size, Cavichioli et al. (2006) referenced genetic characteristics, temperature, number of flowers per plant and fruits in development; grower techniques could directly influence final size, such as irrigation, fertilization and pruning.
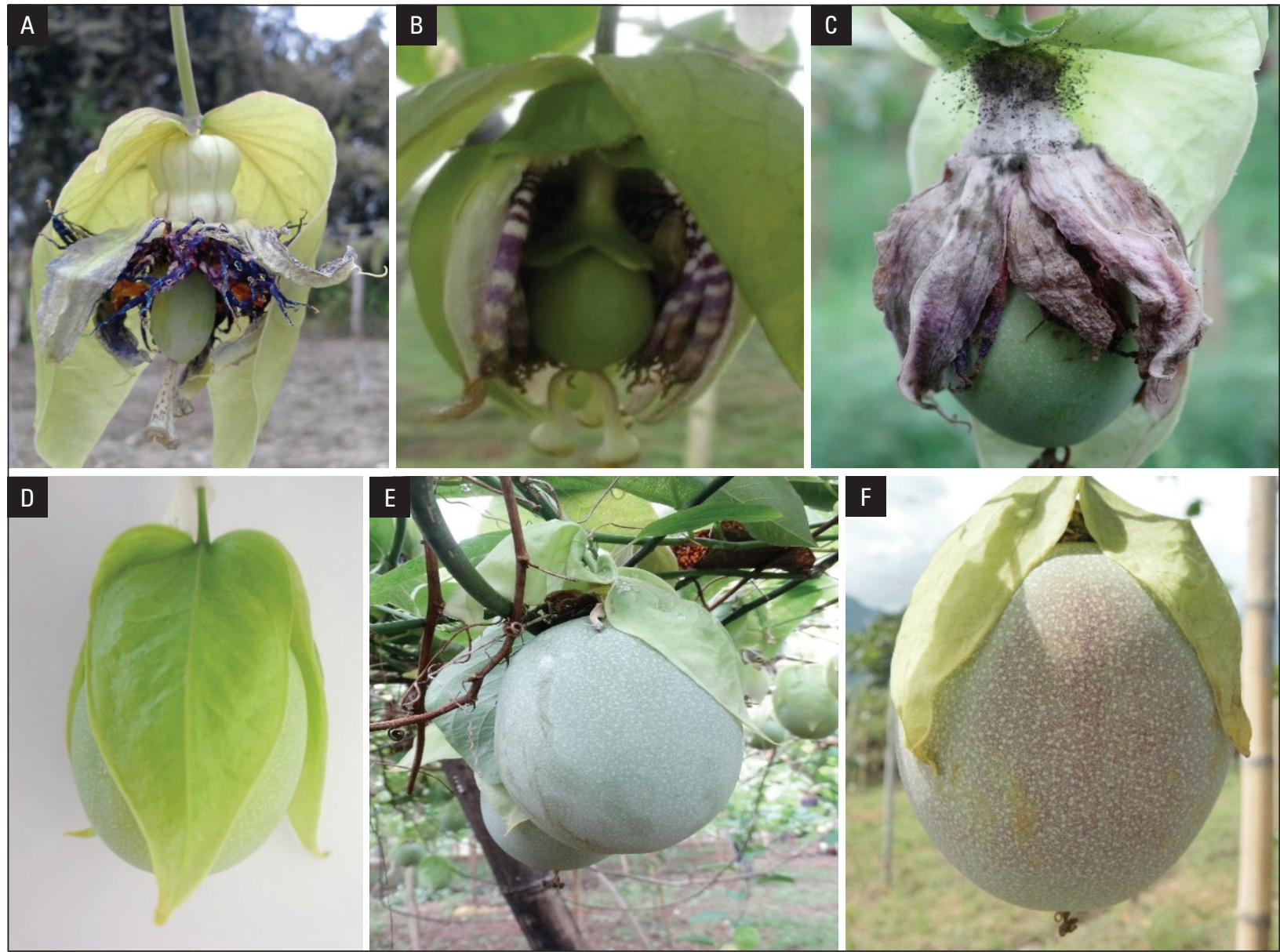

Figure 7. Principal growth stage 7: Fruit development in cholupa (P. maliformis) plants. 7a) Stage 70, visible fruit. 7b) Stage 71, The fruit reaches $10 \%$ of the final size. 7c) Stage 74, the fruit reaches $30 \%$ of the final size. 7 d) Stage 74 , the fruit reaches $40 \%$ of the final size. 7e) Stage 77, the fruit reaches $75 \%$ of the final size. 7f) Stage 79, fruit has reached typical form and size. 

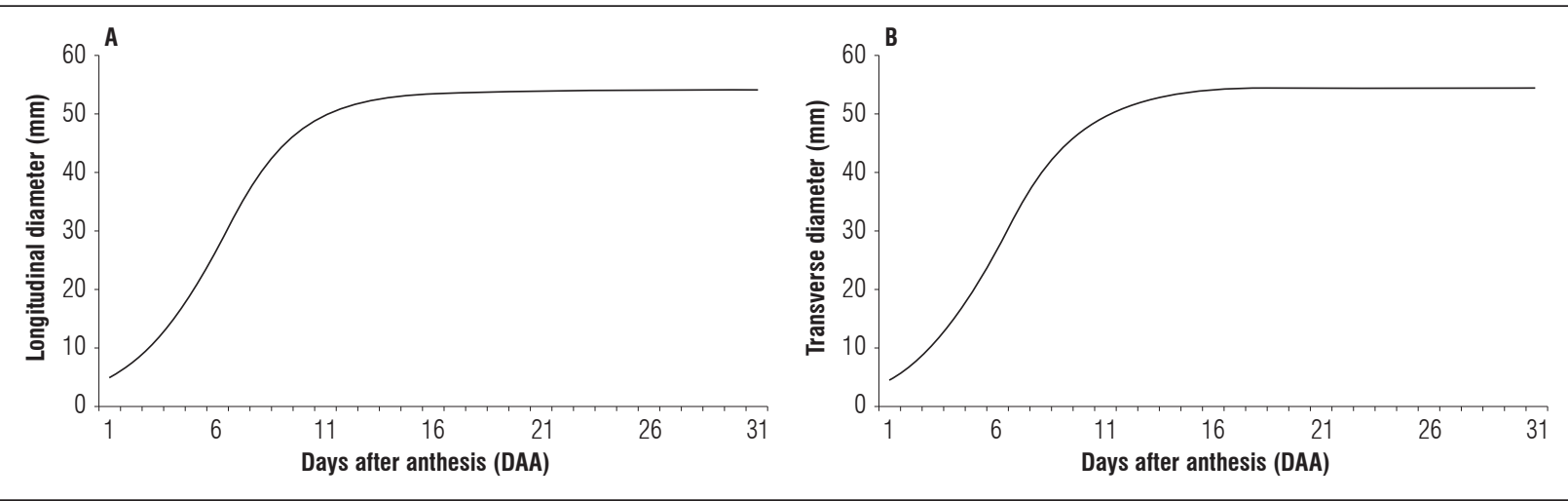

Figure 8. Growth curves adjusted to a logistic model with three parameters of A, longitudinal and B, transverse diameters of the cholupa fruits.

The analyzed variables showed a simple sigmoidal growth pattern (Fig. 8) as the result of the analysis with the fruit weight or size as a function of time (Hunt, 2003). The simple sigmoid pattern is consistent with that found in passion fruits (Arjona et al., 1991) and in gulupas (Lederman and Gazit, 1993). For each variable, the model with the best fit was chosen according to a more homogeneous distribution of the residuals, the highest coefficient of determination for prediction $\left(R^{2}\right.$, Tab. 2$)$, and the lowest mean square error.

The evolution of the longitudinal diameter was adjusted to the logistic model with three parameters, with an $R^{2}$ of 0.87 and a simple sigmoid growth pattern (Fig. 5A). Accelerated growth was observed until 15 DAA, where it tended to stabilize; a similar behavior was found in gulupas by Flórez et al. (2012), in passion fruits by Gómez et al. (1999), and in sweet granadillas by García (2008). The longitudinal diameter presented values very close to the transverse diameter (54 and $53 \mathrm{~mm}$, respectively), which differed from that observed by García (2008) in sweet granadillas and reflected the characteristic spherical shape of cholupa fruits.

The increase in the transverse diameter of fruits was described with the logistic model with three parameters, with an $R^{2}$ of 0.91 (Fig. 5B) and presented a behavior similar to that of yellow passion fruits by Villanueva et al. (1999). In related species, the exponential phase occurs between 7 and 15 DAA, depending on the environment where the fruits grew; the growth rate decreased afterwards and tended to be almost constant after $20 \mathrm{~d}$.
Based on the model adjusted to the fruit growth, it is possible to predict that harvest can be programmed 50 or $60 \mathrm{~d}$ after flowering since the longitudinal and transverse diameters tended to stabilize. The values estimated by the model explained each variable in relation to the field observations and, therefore, properly interpreted the physiological processes taking place in the fruits in each stage.

\section{CONCLUSIONS}

The vegetative and reproductive development phases of cholupa plants established in the province of Huila were described for the first time using the phenological BBCH scale.

The growth pattern of cholupas is a simple sigmoid type with three phases, which may vary slightly depending on the environmental conditions, relative humidity and precipitation.

The logistic model showed a good fit for describing the growth of the fruits under the specific conditions in the municipality of Campoalegre. These models can be used to schedule crop labor and predict the harvest time.

\section{ACKNOWLEDGMENTS}

The authors wish to thank the Huila Governorate, the Huila Technology Corridor Project "Development and implementation of new technologies for the cultivation of cholupa (Passiflora maliformis) as a 
contribution to the strengthening of fruit growing in the Department of Huila" between the years 2014 and 2015, and the Passiflora Technology Development Center Corporation of Colombia - CEPASS for supporting this study. Thanks are extended to the growers and students involved in the field work.

Conflict of interests: The manuscript was prepared and reviewed with the participation of the authors, who declare that there exists no conflict of interest that puts at risk the validity of the presented results.

\section{BIBLIOGRAPHIC REFERENCES}

Agronet. 2019. Estadísticas agrícolas: área, producción, rendimiento y participación 2016. In: http://www.agronet.gov.co/estadistica; consulted: January, 2019.

Almanza-Merchán, P., J. Velandia, and Y. Tovar. 2017. Propiedades fisicoquímicas durante el crecimiento y desarrollo de frutos de lulo (Solanum quitoense Lam.). Rev. Colomb. Cienc. Hortic. 10(2), 222-231. Doi: 10.17584/ rcch.2016v10i2.5065

Arjona, H.E., F.B. Matta, and J.A. Garner. 1991. Growth and composition of passion fruit (Passiflora edulis) y Maypop (P. incarnata). HortScience 26(7), 921-923. Doi: 10.21273/HORTSCI.26.7.921

Cañizares, A., D. Laverde, and R. Puesme. 2003. Crecimiento y desarrollo del fruto de guayaba (Psidium guajava L.) en Santa Bárbara, Estado de Monagas, Venezuela. Revista Udo Agrícola 3(1), 34-38.

Cavichioli, J.C., C. Ruggiero, C.A. Volpe, E.M. Paulo, J.L. Fagundes, and F.S. Kasai. 2006. Florescimento e frutificação do maracujazeiro-amarelo submetido à iluminação artifi cial, irrigação e sombreamento. Rev. Bras. Frutic. 28, 92-96. Doi: 10.1590/S0100-29452006000100026

Fischer, G., F. Casierra-Posada, and W. Piedrahíta 2009. Ecofisiología de las especies pasifloráceas cultivadas en Colombia. pp. 45-67. In: Miranda, D., G. Fischer, C. Carranza, S. Magnitskiy, F. Casierra, W. Piedrahíta, and L.E. Flórez (eds.). Cultivo, poscosecha y comercialización de las pasifloráceas en Colombia: maracuyá, granadilla, gulupa y curuba. Sociedad Colombiana de Ciencias Hortícolas, Bogota.

Fischer, G., L.M. Melgarejo, and J. Cutler. 2018. Pre-harvest factors that influence the quality of passion fruit: A review Agron. Colomb. 36(3), 217-226. Doi: 10.15446/ agron.colomb.v36n3.71751

García, M.C. 2008. Manual de manejo cosecha y poscosecha de la granadilla. Corpoica; Fontagro, Bogota.

Garriz, P.I., H.I. Alvarez, and G.M. Colavita. 2005. Growth pattern of 'AbbéFetel' pear fruits. Acta Hortic. 674, 321-327. Doi: 10.17660/ActaHortic.2005.674.38
Gómez, P.K., E. Ávila, and A. Escalona. 1999. Curva de crecimiento, composición interna y efecto de dos temperaturas de almacenamiento sobre la pérdida de peso de frutos de parchita 'Maracuya' (Passiflora edulis f. flavicarpa Degener). Rev. Fac. Nac. Agron. Medellín $25,125-137$.

Hunt, R. 2003. Growth analysis, individual plants. pp. 579588. In: Thomas, B., D.J. Murphy, and D. Murray (eds.). Encyclopedia of applied plant sciences. Academic Press, London. Doi: 10.1016/B0-12-227050-9/00028-4

Hurtado-Salazar, A., D.F.P. Silva, N. Ceballos-Aguirre, J. Ocampo, and C. Bruckner. 2020. Promissory Passiflora species (Passifloraceae) for its tolerance to water-salt stress. Rev. Colomb. Cienc. Hortic. 14(1), 44-49. Doi: Doi: 10.17584/rcch.2020v14i1.10574

Larcher, W. 2003. Physiological plant ecology: ecophysiology and stress physiology of functional groups. Springer Science and Business Media, New York, NY.

Lederman, I.E. and S. Gazit. 1993. Growth, development and maturation of the purple (Passiflora edulis Sims) the whole fruit. Pesq. Agropec. Bras. 20(10), 1195-1199.

López, I.L., A. Ramírez, and A. Rojano. 2005. Modelos matemáticos de hortalizas en invernadero: Trascendiendo la contemplación de la dinámica de cultivos. Rev. Chapingo Ser. Hortic. 11(2), 257-267. Doi: 10.5154/r. rchsh.2003.08.050

Mayor, B. 2011. Evolución fenológica de las principales especies de frutales en el valle del Ebro. Undergraduate thesis. Escuela Técnica Superior de Ingenieros Agrónomos, Universidad Pública de Navarra, Pamplona, Spain.

Meier, U. 2001. Estadios de las plantas mono y dicotiledóneas, BBCH Monografía. $2^{\text {nd }}$ ed. Centro Federal de Investigaciones Biológicas para Agricultura y Silvicultura. Limburgerhof, Germany.

Melgarejo, L.M. (ed.). 2015. Granadilla (Passiflora ligularis Juss): caracterización ecofisiológica del cultivo. Universidad Nacional de Colombia, Bogota.

Moreno-Medina, B., F. Casierra-Posada, and M. Blanke. 2016. Índices de crecimiento en plantas de mora (Rubus alpinus Macfad) bajo diferentes sistemas de poda. Rev. Colomb. Cienc. Hortic. 10(1), 28-39. Doi: 10.17584/rcch.2016v10i1.4457

Ocampo, J. 2013. Diversidad y distribución de las Passifloraceae en el departamento de Huila en Colombia. Acta Biol. Colomb. 18(3), 511-516.

Ocampo, J., J. Arias, and R. Urrea. 2015b. Colecta e identificación de genotipos de élite de granadilla (Passiflora ligularis Juss.) en Colombia. Rev. Colomb. Cienc. Hortic. 9(1), 9-23. Doi: 10.17584/rcch.2015v9i1.3742

Ocampo, J., A. Rodríguez, A. Puentes, Z. Molano, and M. Parra (eds.). 2015a. El cultivo de la Cholupa (Passiflora maliformis L.), una alternativa para la fruticultura colombiana. Corporación Centro de Desarrollo 
Tecnológico de las Pasifloras de Colombia (CEPASS), Neiva, Colombia.

Rego, G.M., O.J. Lavoranti, and A. Assumpção Neto. 2006. Monitoramento dos estádios fenológicos reprodutivos da Cerejeira Do Mato. Comunicado Técnico 177. Embrapa Florestas, Colombo, Brazil.

Santos, O.A., D.E. Varón, A. Gaigl, and A. Floriano. 2012. Economic injury level for Neohydatothrips signifer (Thysanoptera: Thripidae) in passion fruit at the Huila region, Colombia. Rev. Colomb. Entomol. 38(1), 23-29.

Schwartz, M. 2013. Introduction. In: Schwartz, M.D. (ed.). Phenology: an integrative environmental science. $2^{\text {nd }}$ ed. Springer Science + Business Media, Dordrecht, The Netherlands. Doi: 10.1007/978-94-007-6925-0_1
Seber, G.A.F. and C.J. Wild. 1989. Nonlinear regression. John Wiley and Sons, New York, NY. Doi: 10.1002/0471725315

Silva, F.J.T., M.R.M. Schwade, and A.C. Webber. 2007. Fenologia, biologia floral e polinização de Erythroxylum cf. Macrophyllum (Erythroxylaceae), na Amazônia Central. Rev. Bras. Biociênc. 5(Supl. 1), 186-188.

Tovar, G. 2009. Denominación de origen cholupa del Huila. Gobernación del departamento del Huila. Secretaria de Agricultura y Minería, Neiva, Colombia.

Villanueva, R., S. Evangelista-Lozano, M.L. Arenas-Ocampo, C. Díaz-Pérez, and S. Bautista-Baños. 1999. Evaluación de la calidad del jugo de maracuyá (Passiflora edulis) durante el crecimiento del fruto. Rev. Chapingo Ser. Hortic. 5, 95-101. 10.5154/r.rchsh.1998.11.078 